\title{
"No" and "net" as response tokens in English and Russian business discourse: In search of a functional equivalence
}

\author{
Elena N. MALYUGA ${ }^{1}$ and Michael McCARTHY ${ }^{2}$ \\ ${ }^{1}$ Peoples' Friendship University of Russia \\ Moscow, Russia \\ ${ }^{2}$ University of Nottingham \\ Nottingham, $U K$
}

\begin{abstract}
The literature on English suggests that turn-initial no fulfils a variety of discourse-pragmatic functions beyond its use as a negative response to polar questions. We cannot assume that the same range or distribution of functions is realised by its nearest Russian equivalent, net. Hence, investigating the contrasts and similarities in the nomenclature and distribution of functions of no and net should pose an important research problem for various discourses, and especially for business discourse with its focus on goal-orientation and productive interpersonal relations requiring adequate interlingual interaction. The study examines how no and net occur in two corpora of spoken business/professional discourse in order to establish their functional comparability and reveal the differences in their use. The article draws on data from the Cambridge and Nottingham Spoken Business English Corpus and the Russian National Corpus analysed using a combination of corpus linguistics, conversation analysis and discourse analytical approaches. Study results show some overlap between the functions of the response particles in English and Russian, and some differences. The findings suggest that no/net display a number of functions connected with conversational continuity, topic management, turn-taking and hedging. The distribution and functions of no/net in the English and Russian data are similar, with the Russian data showing a preference for floor-grabbing no-initiated turns. Translation equivalence is not always fully applicable between no and net. A mixed methodology generates results which suggest that fruitful insights can be gained from English and Russian corpus data. The issues of the use of nо and нет in English and Russian business discourses can be further investigated using the suggested data and conclusions.
\end{abstract}

Keywords: business discourse, corpus analysis, negative particle, response token, turn-opener, discourse marker

\section{For citation:}

Malyuga, Elena N. \& Michael McCarthy. 2021. "No" and "net" as response tokens in English and Russian business discourse: In search of a functional equivalence. Russian Journal of Linguistics 25 (2). 391-416. DOI: https://doi.org/10.22363/2687-0088-2021-25-2-391-416 


\title{
«No» и «нет» как ответные единицы в английском и русском деловом дискурсе: в поисках функциональной эквивалентности

\author{
Елена Н. МАЛЮГА ${ }^{\mathbf{1}}$ и Майкл МАККАРТИ ${ }^{2}$ \\ ${ }^{1}$ Российский университет дружбы народов \\ Москва, Россия \\ ${ }^{2}$ Ноттингемский университет \\ Ноттингем, Великобритания
}

\begin{abstract}
Аннотация
Согласно исследованиям, в английском языке частица $n o$, используемая в начале реплики, выполняет широкий спектр дискурсивно-прагматических функций, помимо отрицательного реагирования на полярные вопросы. При этом нет оснований утверждать, что ее ближайший русский эквивалент нет обладает идентичной дистрибуцией и таким же набором функций. В связи с этим исследование контрастирующих и схожих черт в номенклатуре и распределении функций по и нет представляется важной исследовательской проблемой применительно к различным дискурсам, особенно к деловому дискурсу, ориентированному на целеполагание и продуктивные межличностные отношения, требующие адекватного межязыкового взаимодействия. В данной статье анализируется употребление по и нет в разговорном деловом/ профессиональном дискурсе с целью установления их функциональной сопоставимости и выявления различий в их употреблении. Источниками материала послужили Кембриджский и Ноттингемский корпус разговорного делового английского языка и Национальный корпус русского языка. В процессе исследования применялись метод корпусной лингвистики, конверсационный анализ и дискурс-анализ. Проведенное исследование позволило выявить как сходства, так и различия между функциями отрицательных ответных единиц в английском и русском языках. Было установлено, что в обоих языках рассматриваемые единицы реализуют ряд функций, связанных с непрерывностью коммуникативного взаимодействия, управлением темой разговора, меной коммуникативных ролей и хеджированием. Распределение и функции no/нет в сопоставляемых базах данных схожи, при этом в русском языке предпочтение отдается перехвату коммуникативного хода с использованием нет как вступительного элемента реплики. Эквивалентность перевода $n o$ и net не всегда достижима в полном объеме. Использованная в статье смешанная методика позволила получить результаты, продуктивные с точки зрения возможностей компаративного анализа корпусных данных делового английского и делового русского языков. Полученные данные и выводы открывают возможности для дальнейшего анализа употребления по и нет в английском и русском деловых дискурсах.
\end{abstract}

Ключевые слова: деловой дискурс, корпусный анализ, отрицательная частица, ответная единица, вступительный элемент реплики, дискурсивный маркер

\section{Для цитирования:}

Malyuga E.N., McCarthy M. "No" and "net" as response tokens in English and Russian business discourse: In search of a functional equivalence. Russian Journal of Linguistics. 2021. Vol. 25. № 2. P. 391-416. DOI: https://doi.org/10.22363/2687-0088-2021-25-2-391-416

\section{Introduction}

In this article, we investigate the occurrence of English no and Russian net as response tokens in spoken business corpora. By response token we mean the 
occurrence of no, either occupying the entire speaking turn, or in the turn-initial slot of a longer turn and functioning as a response to an immediately previous turn or to a preceding stretch of discourse. We place no within the domain of pragmatic markers, in addition to its commonplace dictionary entry as a negative particle answering polar questions. The turn-initial slot means any place before the main content of the turn is uttered. The scope of our analysis is best illustrated in the following three examples ( $<\$ 1>,<\$ 2>$ indicate first speaker, second speaker, etc.), taken from our English data, which are described in section 3 below.

(1) No as response token occupying the whole turn.

$<\$ 2>$ Have you still not heard anything?

$<\$ 1>$ No.

(2) No as response token in turn-initial position with further talk.

$<\$ 3>$ Is that a problem?

$<\$ 1>$ No. I think that'll be alright.

(3) No as response token in near turn-initial position (e.g. following a discourse marker).

$<\$ 1>[. .$.$] once we've finished the database we're not gonna have to e-mail$ it to each other anyway.

$<\$ 2>$ Well no but it might happen in the future with other stuff.

These will be the principal kinds of uses we are concerned with. Our purpose is to examine how no and its Russian equivalent net occur in two corpora of spoken business/professional discourse. The article is not a corpus-linguistic (CL) study in the sense of quantitative comparisons of parallel corpora, but rather uses the English corpus as a baseline from which to investigate the Russian data using a combination of conversation-analysis (CA) and discourse analysis (DA) insights. The chosen approach has been necessary owing to the lack of equivalence in the compilation, annotation and searchability of the two datasets which makes a fully two-way comparable statistical study impossible (see below). Elsewhere (Malyuga \& McCarthy 2018) we have used the present approach to realise what we believe to be a useful and illuminating analysis of discourse-level features in the two datasets, and we take the same approach here.

\section{Response tokens and no: previous studies}

\subsection{Turn-openings}

The study of response tokens in discourse goes back a long way and has developed under different methodological umbrellas, including CA, DA and CL approaches. Fries (1952: 102-103) looked at a variety of responses during telephone calls, including vocalisations such as unh, hunh, yes and no. Such reactions/responses were not seen as taking over the role of speaker. Tottie (1991: 255) suggests that such response tokens "grease the wheels of the conversation but constitute no claim to take over the turn", like logical connectors do (Wong 2018; Zalizniak \& Paducheva 2018). In multi-party talk of the kind we are investigating, interlocutors do not listen passively and silently; they show listenership using a 
variety of responses which include yes and no as well as fully lexical items, e.g. right, fine, that's good (McCarthy 2002; McCarthy 2003; O'Keeffe \& Adolphs 2008). These types of responses elevate the role of the listener and obviate the tendency to view conversation as "a single speaker's and a single mind's product" (Schegloff 1982: 74). Therefore, we approach occurrences of no as meaningful choices in the co-construction of discourse whose functions must be assessed at the local level of the speaking turn(s) to which they react, in line with CA approaches, and to any discourse that immediately follows, which may be equally illuminated through a DA approach.

Our study has its locus in the turn-initial slot, a place in talk which has been investigated mostly, but not exclusively, within the CA tradition. A pertinent discussion is found in Sacks, Schegloff and Jefferson's (1974: 703) outline of the three internal components of a speaking turn, including a first part which "addresses the relation of the turn to a prior". Later, Schegloff (1996) put forward turn-openers as an example of turn-constructional units, where lexical forms dominate.

Working in the interactional grammar tradition and utilising corpus data, Tao (2003) makes a significant contribution to our understanding of the turn-initial slot. His study concludes that the turn-opening is characterised by items such as yeah, well, right, okay and pronouns introducing fixed expressions such as I think, you know, I mean, that's + adjective (that's right, that's true), etc. Tao's list ranks no as number seven (with yeah at rank four). Tao (2003: 198) assigns yeah and no to the group he calls "assessing", where "agreement/affirmation or disagreement" are enacted. He also sees a functional hierarchy when tokens are combined, for example, a sequence such as $O h, n o, s o \ldots$ at the start of a turn corresponds to a hierarchy of indicating a change in the knowledge state, followed by an acknowledgement or assessment, followed by the "tying" function (i.e. linking to the previous turn).

\subsection{Negation in grammar and discourse}

Studies of negation have considered various possibilities of response to affirmative and negative utterances, both from syntactic and DA viewpoints. Polar, yes-no questions are fully described syntactically by Quirk et al. (1985: 807-810), who also note the conducive aspect of certain types of question (e.g. negative yesno questions) where "the speaker is predisposed to the kind of answer he [sic.] has wanted or expected". This aligns with Pope's (1976: 112) notion of a "negatively pre-supposed question" where a yes-answer might be inappropriate, and echoes arguments proposed by Apresian (2015). However, Bald (1980) had already noted how the positive and negative polarity of yes and no may be neutralised in certain contexts and that the two are sometimes interchangeable in responses showing agreement. Brasoveanu, Farkas and Roelofsen (2013) carried out experiments which included the testing of the viability of yes or no as responses to a range of negative utterances. Their results suggest that the use of yes and no in agreeing correlates with the polarity of the stimulus: "agreeing responses to positive 
assertions only license yes while agreeing responses to negative assertions license both yes and no" (Brasoveanu, Farkas \& Roelofsen 2013: 12) (see also Raymond 2003, on type-conforming and non-conforming responses and Jefferson 2002 on "affiliative" no). Couper-Kuhlen and Selting (2018: 498) consider no responses, mentioning Russian net as a particle for affirmation of a negatively formulated question. They also note that: "The use of the negative polarity particle (no) to preface responses to question-word questions is a widespread practice for resisting the assumptions and presuppositions of the question" (Couper-Kuhlen \& Selting 2018: 524). They also comment on the occurrence of explanations when a negative utterance is produced as a dispreferred response; explanations are expected by recipients and are noticeably absent if not proffered (Couper-Kuhlen \& Selting 2018: 64). This is similar to Biber et al.'s (1999: 1090) reference to the "avoidance of a bleak $n o$ " in a response. These studies underline the claim made by Thompson, Fox and Couper-Kuhlen $(2015: 238)$ that, if taken out of context from the anchorage provided by the previous turn, no is "virtually meaningless".

Lee-Goldman (2011) remarks that yeah has been observed to realise a number of functions, including topic management, while no has been somewhat neglected in this respect. He discusses three discourse-marking functions of no: topic shift, rejecting implicit assumptions or stances by interlocutors and the resolution of turntaking conflicts. Within these three parameters, he concludes, none of the occurrences of no may be the sole item in the speaking turn; further content or elaboration is necessary, and a simple no on its own would be problematic. $\mathrm{He}$ excludes $n o$ as a response to yes-no information questions as being well-studied and understood, and stresses that his study highlights previously unnoticed discourse-marking senses of no. We generally follow his approach but also comment on a sample of no-responses to yes-no questions. In the case of combinations of no with other discourse markers (e.g. but no, well no), Lee-Goldman (2011) advocates treating the contribution of each marker separately, which chimes with Tao's (2003) demonstration of a hierarchy of sequence and function in turn-initiators discussed above.

Lee-Goldman (2011) also notes the use of yeah and no together, either as yeahno or as no-yeah, a phenomenon which Burridge and Florey (2002) had noted in Australian English. They discuss three principal contexts for yeah-no turns: marking assent or dissent, maintaining conversational cohesion, and hedging (see also McGee 2018 on vague language as a means of avoiding controversy and Gribanova \& Gaidukova 2019 on hedging in different types of discourse). Collins (2012: 80) summarises the function of Australian yeah-no: "yeah-no is used where there is agreement yet the speaker wishes to make a negative response to remove any possibility of contradiction".

\section{Data and methodology}

\subsection{Obtaining comparable data}

Elsewhere (Malyuga \& McCarthy 2018) we have discussed issues associated with comparisons of corpora which are not equal in terms of size and 
representativeness within their domains of compilation, methods of annotation or constraints on types of searches. We have acknowledged that the problems of comparability are acute when it comes to spoken corpora and we have accepted the challenges this presents for the kind of inter-linguistic comparisons we hope to make. The ideal data for studies such as ours is naturally occurring, unscripted multi-party talk, which means that it is difficult (indeed impossible) to source identical datasets in different languages and different contexts, or to achieve closely matched content and data quality. Parallel corpora are well-established, where translations of texts from one language into another give access to two comparable datasets (e.g. Johansson \& Hofland 1994; Mikhailov \& Cooper 2016). This is straightforward where written texts and their translations into another language can be placed side-by-side or inter-lineally, yet even here the reliability of the data depends on "translators' competence" (Aijmer \& Altenberg 2013: 2). Building truly parallel corpora of naturally-occurring, unscripted spoken language with all its unpredictability is a challenge of a much greater order. What we can do is to seek to bring together comparable datasets compiled in similar contexts and investigate comparable linguistic phenomena (see the discussion in Beeching 2013).

It is accepted among contrastive linguists that a viable approach for investigating two comparable datasets is the establishment of a tertium comparationis (Egan 2013). In our case, we focus on an act in the turn-opening slot conventionally associated with negative responses to polar questions, but which also might potentially fulfil other discoursal functions, the kind of pragmatic tertium comparationis discussed by Krzeszowski (1984) (see also Connor and Moreno 2005). The tertium comparationis can be at once an anchor for a viable, grounded analysis and a source of insight into previously unnoticed phenomena. In this case it enables an initial comparison of English no and Russian net as typical items occupying turn-initial position and fulfilling a negating function.

Business and professional data are chosen for the present study since they go some way towards reducing unpredictability; they unfold in circumscribed contexts and adhere to well-established conventional boundaries, thus increasing the potential comparability of the datasets. However, we cannot assume completely shared conventions; in an increasingly globalised world, how different cultures express their professional identities invites investigation (Lewis 2019; Malyuga, Krouglov \& Tomalin 2018).

Malyuga and McCarthy (2018) discuss the use of large corpora in the hope that massive amounts of statistical output will yield valid generalisations and obscure local irregularities. However, in contexts such as business and professional discourse, the collection of data is not easy because of issues such as commercial confidentiality, and specialised corpora tend to be smaller for those reasons. It is also arguable that statistical output from huge datasets may tell us less about how speakers interact than the close reading of corpus concordance lines or transcripts in regard to context-bound phenomena such as turn-taking, the power of which both CA and DA have demonstrated (Malyuga, Shvets \& Tikhomirov 2016). Indeed, in relation to no, Lee-Goldman (2011: 2646) states the requirement, for a proper 
analysis, of "a rich representation of the speech context, as it must take into account the prior and projected linguistic context as well as the social and physical contexts of the interaction". CA and DA studies depend on rich contextual information while corpus data tend to be annotated with only relatively broad contextual information, but the power of corpora lies in their ability to reveal the recurrence of features over a number of contexts involving different speakers and utterances separated in time and place.

We believe that, despite the acknowledged problems, useful insights can be achieved using the best sets of comparable data available while accepting the different criteria of compilation, annotation or searchability. The English data we use were collected in more narrowly circumscribed contexts (various types of business meetings), while the available sub-corpus of the Russian National Corpus pulls in a greater range of business and professional talk. Nonetheless, close readings of the data reveal communication patterns recognisable as characterising professional, goal-oriented communities of practice operating within well-defined contextual constraints (Malyuga \& Tomalin 2014). Our two datasets can be considered as comparable but lay no claim to be either parallel corpora or translation corpora (Mikhailov \& Cooper 2016: 4-5). They are as comparable as is practically possible, and, we would argue, two good sources for examining our tertium comparationis.

\subsection{English data}

Our English data come from the Cambridge and Nottingham Business English Corpus (CANBEC), a spoken corpus of just over 900,000 tokens. Detailed information on the corpus and comprehensive analysis of it may be found in Handford $(2010)^{1}$. For the compilation of the corpus, recordings were made at business meetings in the UK from 2001 onwards. The businesses included makers of industrial equipment (e.g. cranes and lifting gear), pharmaceuticals, service industries (e.g. hotel and pub chains, financial services, consultancy). The locations were large and small industrial and service enterprises involving mainly middle- or upper-management UK English speakers, with around 10\% of the speakers being expert users of English as a second language. The meetings included external (intercompany) meetings and internal (intra-company) meetings. Topics of discussion at the meetings ranged from everyday problems and procedures, production schedules, decision-making, logistics, pricing, sales and marketing, to human resources.

\subsection{Russian Data}

The Russian data were derived from the Russian National Corpus (RNC) via a manually filtered sub-corpus of spoken business and professional communication. A few important initial observations need to be made. The RNC is the only major

${ }^{1}$ The CANBEC corpus is Copyright Cambridge University Press, from whom permission to quote or use its data must be sought. 
source of corpus data for Russian, and as such it does not offer ready-made fieldspecific material similar to CANBEC. However, the RNC can be investigated via its in-built search engine, where filters can be applied to narrow down the context (for example, "oral", "business and professional"), a narrowing process which Malyuga and McCarthy (2018) found to yield sufficiently comparable data, and which we apply here.

The overall size of the RNC is over 300 million tokens with the spoken corpus part covering just over 12 million tokens. However, after filters were applied to configure the sub-corpus of spoken business and professional discourse, a total of about one million running words was generated. In view of the similar sizes of the two datasets, raw figures were applied for comparison.

\section{Observations on the English data}

\subsection{Single-word no-turns}

In a search for speaking turns with $n o$ as the first word, retrieved by using "new speaker" tags $(<\$ 1>,<\$ 2>$, etc.), the corpus returned 1309 examples. These were reduced to a random sample of 200 examples for close analysis. The next step was to count how many of the 200 were single-word turns where no was the only word. This figure came out at 77 , around $38 \%$ of the sample. The reason for isolating single-word turns was to assess whether a sole no seemed to be appropriate, given the observations in the literature of the potentially problematic nature of bald no. Here CL yields to DA interpretations, with 27 of the 77 single-word no-turns occurring in response to yes-no questions posed either in interrogative form or statements with different types of question tags. Most of these (21) concern straightforward information that needs to be provided or confirmed; the rest are negative questions seeking agreement from the listener(s). These two types are exemplified in (4) and (5).

(4) Yes/no question: Information provided/confirmed ( $<\$ M>=$ unidentifiable male speaker).

$<\$ 2>$ Isn't there a spec sheet in there?

$<\$ 6>$ No.

$<\$ 1>$ There isn't for any of them is there?

$<\$ M>N o$.

(5) Negative question seeking agreement.

$<\$ 1>$ Well you er just haven't had the time to do that have you?

$<\$ 4>$ No.

$<\$ 3>$ No. We haven't.

The remaining single-word no-turns are dominated by acts of agreement with negative statements, as in (6) (see also $<\$ 3>$ 's response in (5) above):

(6) Confirmation of negative statement.

$<\$ 1>$ The other problem that most people are aware of is that [name of company] aren't able to pay at the moment.

$<\$ 3>$ No. 
(4), (5) and (6) can be interpreted as goal-oriented, economical and efficient: what is required is simple information or agreement with non-controversial conclusions, summaries, judgements, etc., for which a minimal response no is sufficient and is not perceived as abrupt, impolite or face-threatening. These enable business to continue towards its goals without unnecessary delay or discussion. Constant mitigation of bald no may be perceived as unnecessary and frustrating in time-constrained situations.

\subsection{No with further content}

We noted above that some $38 \%$ of no-initial turns were single-word turns. This leaves more than $60 \%$ where no is not alone, but prefaces further conversational actions. One of these is to signal a change in the framing of topic, of which there are 18 examples. No may signal a topic shift, as in (7), often with function of closing or pre-closing the current topic. Example (7) also displays the shift from joking/non-serious talk, indicated by shared laughter, back to serious talk, a phenomenon noted by Schegloff (2001). Lee-Goldman (2011: 2632) asserts that when no signals a topic shift, "the shift is back to a prior topic, rather than a new one". This is confirmed in example (7), where $<\$ 1>$ returns to the topic to make a serious comment after the ironically humorous remark about having just two days to complete a process that was planned a long time before.

(7) Topic shift, including joking to serious [context: logistics meeting at a pharmaceutical company. $<\$$ ? $>$ indicates unidentifiable speaker].

$<\$ 1>$ It's in progress?

$<\$ 5>M m$. Mm.

$<\$ 1>$ But not not not not complete.

$<\$ 5>$ Not complete.

$<\$ 1>$ Okay.

$<\$ 5>$ Mhm.

$<\$ 1>$ And we said by August so you've you know+

$<\$ 5>$ Mhm.

$<\$ 1>+$ got at least two days [laughs]

$<\$ 5>$ [laughs]

$<\$ 1>$ +or whatever.

$<\$ ?>$ [laughs]

$<\$ 5>M m$.

$<\$ 1>$ No okay. So we'll check in next time. [3 secs pause] Erm is there anything else we want to say on the UIN numbers and general export packs?

Example (7) shows the meeting chair using no okay, a combination which accounts for 10 of the topic-shifting turns in the sample. No okay seems primed to signal some change in the topical state. No also combines with so on one occasion in the data where it seems to signal a summarising of the current topic. In example (8) we see this function, but notably, $\langle \$ 3\rangle$, the meeting chair, immediately follows it with so okay, further confirming the shift to a new topic (in this case to discuss a problem with the company's phones line). No/So okay serve to push the immediate business agenda forward. 
$(8)$

$<\$ 3>$ Erm admin. Erm $[1 \mathrm{sec}$.] the equipment index. [1 sec.] is that now wi= That's still not sorted is it.

$<\$ 1>$ No.

$<\$ 2>$ No. So.

$<\$ 3>$ Erm so okay. Well that that then basically [2 secs] I think that once the madness of the de= half term is over erm we've got a little bit of time to do that before Christmas.

No may also function to refute an affirmative assumption or to clear up a misunderstanding, as in (9) and (10). These are less common in the data.

(9) Refuting a statement/assumption.

$<\$ 3>$ And she says that mostly they do get the paperwork in time.

$<\$ 1>$ No. That's not, if you go and look at the stats that are on the web site that Ella produces, seventy-two per cent of last month's I believe paperwork was delivered late...

(10) Misunderstanding.

$<\$ 1>$ The third of July

$<\$ 2>$ The third of July yeah.

$<\$ 1>$ Half, more than halfway through the year.

$<\$ 2>$ No. Because the year starts in April.

Example (10) tallies with Schegloff's (1992) discussion of repair, when a speaker realises their previous utterance has been misunderstood. In one case, no signals agreement that the situation is problematic or undesirable, even though the utterance(s) it reacts to are not syntactically in negative form:

$<\$ 2>$ So it would be a hundred times a hundred and ninety is the bill we'd get.

$<\$ 3>$ Well let's assume that's the worst case.

$<\$ 2>$ No. Let's assume that's the worst case.

$<\$ 3>$ That's the worst case.

$<\$ 2>$ Right.

Requests and directives may be responded to negatively with $n o$, though it has been hard to find examples in our data, and where they occur, there is some sort of mitigation, explanation or softening, for example with laughter, as in (12), which also includes a no signalling misunderstanding, as in (10) above:

(12) Mitigated/softened no; second no corrects misunderstanding.

$<\$ 1>$ Could you price it up and see how much it is? I mean we only need one.

$<\$ 2>$ Yeah. They're about, they're eighty quid.

$<\$ 1>$ Can we have one and copy it?

$<\$ 2>$ No. Cos it's about five thousand pages. [laughs]

$<\$ 1>$ No. Imean +

$<\$ 7>C D$.

$<\$ 1>$ +one disk and copy it.

$<\$ 2>$ Oh right. 
A further function is to preface or bracket a directive which counters another speaker's assessment of the turn-taking process, in this case in a conventional expression associated with the management of turns (carry on):

(13) Negative directive/turn management.

$<\$ 4>$ I'm sorry I'm butting in.

$<\$ 1>$ Oh no no. You carry on. No.

Examples (1) to (13), all of which come from the English data, cover canonical discoursal and pragmatic functions of no. Other functions are possible, though not attested in our data, for example, response to a negative directive (as in this recently heard example: "Don't forget your gloves". - "No. Thanks for reminding me").

\subsection{No combined with other pragmatic markers}

From a DA perspective, no may be followed by other markers such as but and because. No but is the most frequent collocation, with nine examples in our random 200 sample, followed by no okay, with eight examples, no because/cos, with seven occurrences. No but indicates partial agreement with a negative utterance, or one that indicates a problematic situation, followed by some element of correction or modification, as in (14).

$<\$ 2>$ Yeah but if they'd already conferred obviously then he wouldn't have had a start date surely. Because that process would have occurred.

$<\$ 1>$ No but they had a start date subsequently didn't they.

No because-turns offer an explanation or elaboration in cases where a bald no could be inadequate or face-threatening for either the speaker or listener(s):

$<\$ 3>$ You haven't got any idea roughly what you think we'll be paying.

$<\$ 1>$ No because it's a bit complicated. I'll have a word with a colleague of mine to make sure I've done this right and he agrees with me.

\subsection{No preceded by other markers}

Other markers may precede no in the turn-initial slot. Most frequent are oh no and well no. Oh no signals a reaction of surprise or that something is problematic. Heritage (2002) sees $o h$-prefaced disagreement as "upgraded" relative to the same response without $o h$. An extreme case of an $o h$-prefaced no is (16), where $<\$ 4>$ has been listing a catalogue of worrying price increases, culminating in "step lifts" and "tail lifts".

$<\$ 4>$ Step lifts have gone up three percent. [1 sec.] Tail lifts +

$<\$ 5>$ Oh no no no no no no no no. We need to talk about this.

$<\$ 4>+$ tail lifts gone up three percent. 
Well softens no, making it less blunt and face-threatening, as in (17), which also has a cos-prefaced explanation/elaboration:

$<\$ 2>$ Who who's dealing with this at Unico? Tom?

$<\$ 1>$ Well no cos he's only renewals. So he put me through to someone that

deals with new

registrations...

In (17) we also see clear evidence of Tao's (2003) observations on the sequencing of items (change of knowledge state + assessment + tying; see above).

\subsection{Yeah-no and no-yeah}

As noted in the review of previous studies, attention has been paid to what, on the face of them, appear to be combinations of contradictory markers: yeah-no and no-yeah. Yeah-no occurs four times in our 200 sample. No-yeah occurs twice. Example (18) shows the dual functioning of yeah-no discussed by Lee-Goldman (2011) and is typical of the occurrences in our data.

(18) $[<\$ 1>$ is proposing to join a professional organisation and wonders how she will pay the membership fee.]

$<\$ 1>$ Well do you $=$ How does that work? Do you pay your own membership or does the business pay it?

$<\$ 2>$ The business pays it.

$<\$ 1>$ Would the business pay mine?

$<\$ 2>$ Yes.

$<\$ 1>$ All right then. I'll do it then.

$<\$ 2>$ [laughs]

$<\$ 1>$ Well I would do it to be honest I would do it even if you didn't but er

I'd have to say I'd struggle to afford it.

[1 sec.]

$<\$ 2>$ Yeah. No. We'll we'll, the business will pay for that.

Here $<\$ 2>$ seems to be agreeing that it would be a struggle for the individual to pay (yeah), then counteracts (no) the possibility that $<\$ 1>$ may think it problematic by restating the company's position.

\subsection{Multiple no}

We saw in example (16) above how a speaker used eight no's in succession in reaction to a highly problematic situation. Eight successive occurrences are exceptional; however, the data sample also includes an occurrence of five no's in succession, with four and three no's showing one example for each, and there are 12 occurrences of two no's. Repeated no's are an example of what Stivers (2004: 288) calls "multiple sayings", which she sees as "an interactional resource for speakers to display their talk as addressed to a larger course of action rather than only to the just prior unit of talk". Example (16) above demonstrates this function 
in that the repeated no's are a reaction to a previous list of problematic increased charges extending over a number of speaker turns.

\section{Comparisons with the Russian data}

\subsection{Net occupying the whole turn}

As noted, this study is not concerned with side-by-side comparison of English and Russian data, but rather uses insights from the English data as a point of departure for the mapping and comparison of the occurrences of no and net. With this in mind, the features associated with no were explored in the Russian data (e.g. as a single-word turn, as an item preceding further content, preceded by other pragmatic markers, etc.). Following the filtering procedure, net was marked as the first item in the speaking turn in the RNC "additional attributes" tab, with the search yielding 1212 examples. For consistency reasons, these were further reduced to a 200 random sample for close analysis.

A difference in the occurrence of single-word no- and net -turns emerged in the initial comparison, with only 31 examples registered in the RNC sample, which makes for a percentage difference of $15 \%$ vs $38 \%$ of single-word occurrences in the Russian and English data, respectively. At the same time, assessment of the functional load of net as an item occupying the entire speaking turn revealed no notable discrepancy when compared to no. The following examples demonstrate the affinity of the three basic functions of single-word net-turns to the English noturns:

(19) Answer to a yes/no question.

$<\$ 1>$ A povestki vam prikhodili? [And have you received any summons?]

$<\$ 2>$ Net. [No.]

(20) Answer to a negative question that seeks agreement.

$<\$ 1>$ Ehto ne pomeshaet vam $v$ smysle soblyudeniya srokov? [Will this stand in the way in terms of deadline management?]

$<\$ 2>$ Net. [No.]

(21) Confirmation of a negative statement.

$<\$ 1>$ No tol'ko nel'zya pozvolit', chtoby, chtoby vot ehti tsifry ne soshlis'.

[It's just that we can't, we can't let these figures fall apart.]

$<\$ 2>$ Net. [No.]

$<\$ 3>$ Net, konechno. [No, of course not.]

Thus, as far as single-word turns are concerned, the discrepancy only has to do with a quantitative difference in the occurrence of no and net, which could be attributed to a more pronounced proclivity towards floor-grabbing conversational actions in the practices of communicative exchange in the Russian linguaculture, though this has to remain speculative.

\subsection{Net followed by further talk}

A disposition towards floor-grabbing talk stood out more as net was, at the next stage, analysed as a turn-opener followed by further content (169 examples, 
amounting to $85 \%$ of the sample). While its functional scope could be once again placed on the same footing as that described for the English data (e.g. topic management, repair, face protection), an important difference had to do with the type of the immediately prior turn, which in case of the Russian sample was more prevalently (92 out of 169 examples) represented by assertions rather than questions:

(22) Shift to a new topic.

$<\$ 1>N u$, konechno, assortiment-ehto otdel'nyi vopros. [Well, product range is obviously a separate issue.]

$<\$ 2>$ Net, voobshche znaete, chto interesno, to est', konechno, den'gi kolossal'nye vkladyvayutsya, a my ved' vse-taki uzhe davno vodoi zanimaemsya uzhe, da? Vot nam po mnogim momentam interesno, potomu chto, vo-pervykh, tam u nikh est' brendy, to est' "Essentuki", naprimer... [No, you know what's interesting is that the money that goes in it, I mean, it's colossal, and we have been in the water business for a long time now, right? It's just there's a lot of aspects and it's interesting, because for one thing, they have brands, I mean like "Essentuki", for example...]

(23) Topic shift, including joking to serious.

$<\$ 1>$ Sobstvenno, $v$ malykh kompaniyakh sisadmin - ehto golovnaya bol' [smekh]. I... normal 'no ehto nachinaet rabotat', kogda ehto shtat tam iz pyati tire desyati ili bolee aitishnikov pri kotorykh est' ee... posrednik-nachal'nik. [Actually, in small companies, a sysadmin is a headache [laughter]. And ... it normally starts working when it is a staff of five to ten or more IT guys who have uh ... a mediator boss.]

$<\$ 2>V$ obshchem, u vas aitishnik - on tozhe golovnaya bol' [smekh]. [So basically, an IT guy is a headache for you just as well [laughter].]

$<\$ 1>$ Net, u nas ne aitishnik... Nu, v smysle aiti-otdel. [No, it's not just an IT guy... I mean, we have an IT department.]

$<\$ 3>$ Net, u nas bol'shoi aiti-otdel, on rabotaet $i$ na osnovnuyu kompaniyu, $i$ na filialy. [No, we've got a big IT department, it works for both the main office and the subsidiaries.]

(24) Refuting a statement/assumption.

$<\$ 1>$ No, tem ne menee, znachit $v y$, opredelyaya ehtu tsenu, iskhodili tol'ko iz realii rynka + [But, nevertheless, it means that when determining this price, you proceeded only from market realities + ]

$<\$ 2>D a$. [Yes.]

$<\$ 1>+$ a ne pytalis' poschitat' skol'ko vy-to sami tratite na personal i tak dalee. [ + rather than trying to calculate how much you yourself spend on staff and so on.]

$<\$ 2>$ Net, my znaem skol'ko my tratim, my znaem svoyu sebestoimost', ee... To est' $v$ printsipe my rabotaem dazhe seichas, rabotaem $v$ plyus. [No, we know our expenditures, we know the costs uh... I mean, basically, we are working, even now we are reaching profitability.]

(25) Correcting a misunderstanding.

$<\$ 1>$ Znachit, vsego dvadtsat' pyat' pozitsii. [So, it's a total of twenty-five items.] 
$<\$ 2>$ Dvadtsat' pyat', da, v obshchei slozhnosti. [Twenty-five, yeah, collectively.]

$<\$ 1>$ Poluchaetsya $s$ uchetom dvadtsati pyati pozitsii $v$ nedelyu... [So, considering it's twenty-five items a week...]

$<\$ 2>$ Net, ehto kazhdyi den'. [No, it's per day.]

(26) Mitigated/softened net.

$<\$ 1>$ Transport uzhe organizovan, naskol'ko ya ponimayu. [I take it the transport is taken care of.]

$<\$ 2>N u$, tipa marshrutnykh taksi, navernoe. [I guess it's something like shuttle buses.]

$<\$ 3>$ Net. [No.]

$<\$ 4>$ Net. [No.]

$<\$ 3>$ Net, tam gruzovaya, po-moemu. [No, it's a truck I think.]

As illustrated by examples (22) to (26), turn-initial net is often not about providing a straightforward answer to a straightforward question: just as is the case with the English data, it appears to be intertwined with communicative goals characteristic of business and professional contexts on different levels, fulfilling a variety of functions connected with goal-orientation and interpersonal relations. This once again highlights the complex functional nature of both no and net, where use in both languages often involves applying "indirect strategies as well as mitigating devices to avoid threatening the initiator's positive face" (Iliadi \& Larina 2017: 538).

\subsection{Net preceding other pragmatic markers}

The next stage of the comparison, the interplay of no/net with ambient pragmatic markers, revealed some interesting differences in the two datasets. While the English business data contains examples where no is followed by pragmatic markers, including no but, no because/cos, no okay and no so, the English-toRussian comparison only registered a noticeable similarity between no but and its translation equivalent net no fulfilling the same two functions:

(27) Indicating partial agreement with a negative utterance.

$<\$ 1>N u, v$ takom sluchae my poka ne budem speshit's ehtim voprosom.

[Well, if that's the case, we won't rush on that for now.]

$<\$ 2>$ Net, no nuzhno tol'ko oboznachit' obshchuyu strategiyu, inache my...

ehto vse prosto otlozhitsya $v$ dolgii yashchik. [No, but we just need to designate a general strategy, otherwise we... we'll just force it all onto the back burner.]

(28) Highlighting a problematic situation followed by some element of correction, modification or expansion.

$<\$ 1>N u$ i khorosho. Lyudei nabrali znachit, nu vot, a ty govorish' - tut rabotat' nekomu. Aleksei zhe ostalsya. [Well that's fine then. We've hired people, there you go, and you say there's no one left to do the work. Alex stayed on, right?] 
$<\$ 2>$ Net, no tam slozhno odnomu... Ego voprosami dergayut postoyanno to odno, to drugoe... Eshche Popov zvonit - govorit tam transportirovochnuyu markirovku zakazyvali nedavno, voprosov kucha. [No but it's complicated to handle on your own... He's pestered all the time with so many questions - it's just one thing after another... And Popov keeps calling - says they ordered shipping markings a while back, there's lots of issues.]

One other function of net, no in the Russian data can be singled out, especially in the context of business communication, which generally avoids face threatening acts. This function of net, no implies explicit disagreement and even reproach, which is evident because it does not constitute a response in a conventional sense, but rather comes as a reaction to an assertive statement and involves retrospective reference to a previous stretch of discourse, evidently reminding the speaker of their questionable reasoning in the light of previous discussions:

$<\$ 1>$ Unas net problemy segodnya po vedushchim gorodam strany, u nas net problemy po evropeiskoi zone. U nas segodnya problemy svyazany s drugim. [We have no problems today with the leading cities of the country, we have no problem in the European zone. Our problems today have to do with other things.]

$<\$ 2>$ Net, no po evropeiskoi zone ya vam privel v primer Yaroslavl'... [No but with the European zone I singled out Yaroslavl as an example...] $<\$ 1>N u$, i v Yaroslavle, i v Moskve est' neplatel'shchiki, kotorym my ne budem postavlyat' ni odnogo kilovatt-chasa, a platel'shchikam my budem postavlyat' $v$ polnom ob'eme. [Well, both Yaroslavl and Moscow have delinquent payers, and they won't get a single kilowatt-hour, while to the payers we will deliver in full.]

This particular conversational action, however, cannot be labelled as "typical" of Russian business discourse, as our sample only provided a single occurrence. Therefore, there is no evidence to suggest that Russian business and professional discourse practices are more prone to face threatening conversational actions than English. Besides, much will depend on the context of utterance, in particular whether the conversation is taking place as part of inter- or intra-company interaction, the latter being the case here, which might sanction more unrestricted conversational patterns (see Handford 2010 for discussion of the intra/inter distinction in business discourse).

No comparable examples were found in the Russian sample to evidence formal or functional parallels with no because/cos, no okay or no so. Instead, the most frequently occurring combination, net, $n u$, was found to fulfil at least three prominent functions as shown in (30) to (32) below. Notably, this is where issues of equivalence emerge, specifically because while the two elements making up the combination can be readily translated $(n e t=n o, n u=w e l l)$, their combination adds up to a conversational unity very much dependent on the context and therefore not so easily correlated with any of the possible English counterparts: 
(30) Casual correction of previous assertion.

$<\$ 1>$ Startovyi kapital, naskol'ko ya ponyala, u vas byl sto pyat'desyat tysyach rublei? [You had a starting capital, as I understand it, it was around a hundred and fifty thousand rubles?]

$<\$ 2>D a$. [Yes.]

$<\$ 1>$ To est'vy... [So you...]

$<\$ 2>$ Net, nu iznachal'no on byl okolo sta... Okolo sta tysyach rublei.

[No, I mean initially it was about a hundred... About a hundred thousand rubles.]

In this case, I mean can be viewed as the closest equivalent to net $n u$ inasmuch as it correlates with the idea of conversational repair. Even though no well might seem fitting in this context, it does not fully embody the pragmatics of remedial action which the Russian expression does.

(31) Making the statement sound matter-of-course, self-evident.

$<\$ 1>N u$, s nalogooblozheniem tut mogut vozniknut' problemy, nekotorye tak

$i$ ne vytyagivayut, bankrotyatsya... [Well, taxation problems may arise here, some people fail and go bankrupt...]

$<\$ 2>$ Net, $\boldsymbol{n u}$ kto bankrotitsya, tot bankrotitsya, a tak kto im meshaet seichas otkryt' svoe delo - pozhaluista otkryvai. No ne u vsekh, konechno poluchitsya, poehtomu lyudi rabotayut na okladakh, starayutsya prodvinut'sya po sluzhebnoi lestnitse. [Well, some do and some don't, but otherwise no one stands in their way if they want to start their own business - just go ahead and do it. But not everyone will succeed, of course, which is why people work for salaries and try to progress up the career ladder.]

Example 31 is an illustrative case of translational mismatch between the two languages, as a word-for-word equivalence would risk being overburdened with the negating semantics of no. A freestanding well, on the other hand, in this particular context, inherently incorporates the pragmatics of partial agreement coupled with evidentiality, which is highlighted by the immediately following content - "some do and some don't'.

(32) Hedging.

$<\$ 1>$ A po normativam oni vse sdayut? [And do they reach the qualifying standards?]

$<\$ 2>$ Net, nu kak sdayut... V smysle, po nashim zayavkam ili voobshche?

[Well no, I mean... You mean according to our requests or in general?]

The proposed match in this case is only a suggested framework for equivalence, because to all intents and purposes any kind of hedging, including hesitation markers such as $m m m, u h, h m$, etc., would be fitting in this conversational environment. Examples (30) to (32) evidence a specific Russian conversational collocation of net and $n u$, which is not readily correlated with possible English counterparts and not openly accessible for comparison function-wise. 


\subsection{Net preceded by other markers}

On the one hand, the Russian data provide examples of nu net as equivalent to the English well no and fulfilling a similar function of softening a negative response and making it less face-threatening:

$<\$ 1>$ Pravda, ona vmig na vosem' ne vyrastet... Eheheh, proidet kakoe-to vremya, vozmozhno... [Although it won't rise by eight points in an instant... Umm, it'll take some time, perhaps...]

$<\$ 2>N u$, vot ya, dopustim ya kupila, vybrala ya kakuyu mne aktsiyu pokupat'... Snachala luchshe odnu kupit' ili nuzhno srazu neskol'ko? [Well, I... Let's say I bought, I made my choice and I know which stock I want to buy... Do I buy one for starters or do I need to buy several stocks at once?] $<\$ 1>\mathrm{Nu}$, net, s odnoi neudobno, potomu chto vy bol'she poteryaete na komissii brokera. [Well no, one will be impractical, because you will lose more on broker commission.]

On the other hand, oh no is not represented in the Russian sample at all, which is probably because its translation equivalent $o$ net is not typically used in everyday spoken discourse, much less in business and professional settings, and would be more at home in theatrical discourse as it implies an overly-dramatic, emotionally driven exclamation.

\subsection{Da net / Net da}

The Russian business and professional data contain a number of examples of da net (literally yes no) used to perform a variety of functions. Notably, da net cannot be viewed as a freestanding occurrence of net accompanied by $d a$, because the two items form a fixed expression. The expression is not associated with the semantic duality inherent in the English yeah-no and no-yeah responses, and is therefore not so obviously equivalent to yeah no or no yeah but is used for several unitary functions, including, but not limited to the following three:

(34) Amplification of negation ( $d a$ as an emphatic particle amplifying the net part of the answer).

$<\$ 1>$ Posredniki segodnya - ehto vladel'tsy munitsipal'nykh setei. Ya ne mogu podavat' ehlektroehnergiyu, polozhiv ee $v$ yashchik $i$ otnesya ee na $k v a r t i r u$. [Intermediaries today are the owners of municipal networks. I cannot supply electricity, putting it in a box and taking it to the apartment.]

$<\$ 2>$ To est' ehto zavisit ot mestnykh vlastei? [So it depends on the local authorities?]

$<\$ 1>$ Da net, delo ne $v$ tom, ot chego zavisit. Delo $v$ tom, chto tekhnologicheskie posredniki $v$ ehnergetike. [No, it's not about what it depends on. It's about technological intermediaries in the energy sector.]

(35) Confident dismissal of the proposed opinion.

$<\$ 1>$ My tut govorili pro ofshornye tekhnologii. [We were talking about offshore technology here.] 
$<\$ 2>D a$, ehto, navernoe, khorosho. Budem kak Indiya, govoryat. [Yeah, this is probably a good thing. We'll be like India, they say.]

$<\$ 3>$ Da net. Vot irlandskaya model' mne bol'she nravitsya. [Well no. I like the Irish model more.]

(36) Correcting misunderstanding (in a manner that can be described as edgy or impatient).

$<\$ 1>$ To est' tysyachu na sem'desyat-vosem'desyat, ehto skol'ko zh poluchaetsya na litso-to? [So a thousand to seventy-eighty, then how much does it add up to per person?]

$<\$ 2>$ Arenda voobshche sostavlyaet $v$ nashei raskhodnoi chasti gde-to tam tridtsat'-sorok protsentov. [Rent in general makes up around thirty-forty percent in our expenditure side.]

$<\$ 1>$ Da net, ya pro metrazh, vot skol'ko metrov nuzhno dlya cheloveka, chtoby on normal'no sebya chuvstvoval? Iz chego vy iskhodili pri raschetakh? [No, I'm talking about the footage, I mean how many meters do you need per person to make them feel comfortable? What was your point of departure in the calculation?]

These examples underscore the emphatic nature of $d a$ used to highlight negation together with the immediately sequential conversational content. With no direct equivalent, we here substitute the fixed expression by plain no or well no.

\subsection{Multiple net}

The Russian data provided examples of the function of multiple no described for the English data - displaying the talk as addressed to a larger course of action rather than to the just prior unit of talk:

$<\$ 1>$ A stoimost' proekta my ne uvelichivaem? [And don't we raise project costs then?]

$<\$ 2>$ Net, stoimost' nikak ne izmenyaetsya, ona mozhet razve chto tol'ko ponizhat'sya u nas. [No, the cost won't change, it can only go down for that matter.]

$<\$ 1>$ Prosto ehto printsipial 'nyi vopros. [It's just it's a principal question.]

$<\$ 2>$ Net-net-net, amortizatsiya nachislyaetsya, i ostatochnaya stoimost' men'she delaetsya konechno. [No no no, they charge depreciation and the net book value is decreasing obviously.]

The Russian sample also included a set of examples where multiple net fulfilled several sub-functions, exemplified here in (38), (39) and (40):

(38) Boosted net.

$<\$ 1>$ Pro oborudovanie ponyatno. To zhe samoe esli my pokrasili dopustim kakoe-to pomeshchenie kraskoi, a pochemu dolzhna stoimost' menyat'sya ot ehtogo? Ne izmenitsya, konechno. [I get it with the equipment. The same thing if we painted, let's say we painted some facility, then why should the cost change because of that?] 
$<\$ 2>A$ esli pomenyali poly, pomenyali kryshu? [And if we changed the floors, or changed the roof?]

$<\$ 1>$ Net-net, kapital'nyi tekushchii remont ne uvelichivaet osnovnuyu stoimost'. [No no, scheduled maintenance doesn't increase the basic cost.]

(39) Turn-grabbing.

$<\$ 1>$ Vot $v$ printsipe, na samom dele, na kakom ehtape oni dopustili zaderzhku postavok? [Well actually, as a matter of fact, at what stage did they delay delivery?]

$<\$ 2>$ Minutochku... [Wait a minute...]

$<\$ 1>$ Net-net, ya proshu proshcheniya, ya tol'ko khochu utochnit', prosto vazhnyi zhe vopros. [No no, I'm sorry, I just want to clarify, it's just it is an important question.]

(40) Acknowledging understanding.

$<\$ 1>$ Tak chto dal'she? Vot ehti tsifry? [So what's next? These numbers here?]

$<\$ 2>$ Vot gde-to dve pozitsii tam bylo, vo vtoroi kolonke. Vot, tam na shest' tysyach. [There were two positions there somewhere, in the second column. Here, it's six thousand in total.]

$<\$ 1>$ Net-net, ya ponyal, ponyal, ehto yasno. [No no, I get it, I get it, it's clear.]

These occurrences probably bear evidence of a more pronounced tendency towards mildly emphatic responsive action in Russian, though again, this is offered as no more than a plausible inference.

\section{Discussion}

\subsection{The English data}

The English sample confirms many of the insights arrived at by previous CA/DA studies of no. However, worth pointing out in the present context is the unproblematic nature of single-word no-turns where the quick and efficient exchange of information or assessment is imperative. The agreement function of no also indicates convergence, an important goal of business/professional talk, especially in situations of negotiation and decision-making. Elaboration of the turn after an initial no is a strategy to avoid divergence and to mitigate dispreferred or problematic responses. The noticeable frequency of no as a topic-management marker reflects the nature of business meetings, which typically work purposefully through an agenda where topical focus equates with efficiency and where unmanaged topic drift would be undesirable, unlike everyday social conversation, where topics may meander through unpredictable and unplanned pathways.

\subsection{The Russian data}

The Russian data largely support the conclusions drawn from the English data. The Russian data suggest a general preference for extended turns with net followed by further talk and present us with evidence of net following both questions and assertive statements, with a number of examples testifying to net being a reaction 
to the latter. The Russian sample would seem to come out as potentially more inclined toward floor-grabbing turns in the environment of net. Only one apparent, but not certain, threat to face was detected. The study also highlighted some combinations, such as net, $n u$ and da net, which are particular to the Russian language and which present problems of item-to-item equivalence.

\section{Conclusion}

The paper addressed an issue at the intersection of CA and DA, namely the functions of negative particles - English no and Russian net - in turn-construction, as response tokens in English and Russian business and professional discourse. We aspired to establish functional comparability between single no and net while suggesting differences in the use of these particles in combination with other pragmatic markers. The article used CL-derived samples to explore the functional range of the particles. A sample from a spoken business English Corpus (CANBEC) was used to explicate the occurrence of no in turn-initial positions, while the Russian National Corpus sample was similarly analysed against the backdrop of the English data.

This study has involved three stages of analysis of our tertium comparationis. The first stage involving the analysis of no and net as single-word turns suggested a good correlation of functions across the two languages with only a slight difference in frequency. At the next stage, occurrences preceding further content were also assessed as similar function-wise, although responses in the Russian data were found to be more often a reaction to assertive statements rather than questions, which is why the Russian examples were assessed as showing a possible proclivity towards floor-grabbing. The most apparent dissimilarities were briefly discussed at the final stage that involved examination of other discourse markers either preceding or following no and net.

Whereas cultures may often differ in the linguistic realisations of pragmatic functions such as (dis)agreement, hedging and face protection, the global worlds of business and professional discourses may be expected to show more cross-cultural similarities in terms of goal-oriented conversational practices. Business and professional discussions needs must prioritise temporal efficiency and constrained topic management, while endeavouring to create and maintain good working relations with colleagues, clients and other discursive partners.

Yet the study has revealed that establishing equivalence within tertia comparationis is never a straightforward matter and we have suggested that net is not always the best match for no when it combines with other pragmatic markers. This conclusion aligns with some of the discussions in Heritage and Sorjonen (2018), where "untranslatable" particles in various languages bear functional loads which sometimes seem to overlap with some of the functions we discuss here. Such differences and overlaps are made plain in the contexts of naturally-occurring data, with all the challenges of comparability that these throw up. A combination of CA, DA and CL approaches yields a more nuanced picture than any of the three taken 
separately. We conclude that corpora of unscripted talk from similar, constrained contexts across languages can be fruitfully exploited both quantitatively and qualitatively even though they are never likely to be parallel.

(C) Elena N. Malyuga \& Michael McCarthy, 2021 @creative

This work is licensed under a Creative Commons Attribution 4.0 International License https://creativecommons.org/licenses/by/4.0/

\section{Acknowledgements}

The authors thank Dr Jane Evison, School of Education, University of Nottingham, for her helpful contributions during the earliest stages of the research which led to the present article. This publication has been supported by the RUDN University Strategic Academic Leadership Program.

\section{REFERENCES}

Aijmer, Karin \& Bengt Altenberg. 2013. Introduction. In Karin Aijmer \& Bengt Altenberg (eds.), Advances in corpus-based contrastive linguistics: Studies in honour of Stig Johansson, 1-6. Amsterdam: John Benjamins.

Apresjan, Valentina Ju. 2015. Concessivity: Mechanisms of Formation and Interaction of Complex Meanings in the Language. Moscow: Languages of Slavic Cultures.

Bald, Wolf-Dietrich. 1980. Some functions of "yes" and "no" in conversation. In Sidney Greenbaum, Geoffrey Leech \& Jan Svartvik (eds.), Studies in English linguistics for Randolph Quirk, 179-191. London: Longman.

Beeching, Kate. 2013. A parallel corpus approach to investigating semantic change. In Karin Aijmer \& Bengt Altenberg (eds.), Advances in corpus-based contrastive linguistics: Studies in honour of Stig Johansson, 103-125. Amsterdam: John Benjamins.

Biber, Douglas, Stig Johansson, Geoffrey Leech, Susan Conrad \& Edward Finegan. 1999. Longman Grammar of Spoken and Written English. London: Longman.

Brasoveanu, Adrian, Donka Farkas \& Floris Roelofsen. 2013. N-words and sentential negation: Evidence from polarity particles and VP ellipsis. Semantics and Pragmatics 6. 1-33. DOI: https://doi.org/10.3765/sp.6.7

Burridge, Kate \& Margaret Florey. 2002. "Yeah-no he's a good kid": A discourse analysis of "yeah-no" in Australian English. Australian Journal of Linguistics 22 (2). 149-171. DOI: https://doi.org/10.1080/0726860022000013166

Collins, Peter. 2012. Australian English: Its evolution and current state. International Journal of Language, Translation and Intercultural Communication 1 (1). 75-86. DOI: https://doi.org/10.12681/ijltic.11

Connor, Ulla M. \& Ana I. Moreno 2005. Tertium Comparationis: A vital component in contrastive research methodology. In Paul Bruthiaux, Dwight Atkinson, William G. Eggington, William Grabe \& Vaidehi Ramanathan (eds.), Directions in Applied Linguistics: Essays in Honor of Robert B. Kaplan, 153-164. Clevedon: Multilingual Matters.

Couper-Kuhlen, Elizabeth \& Margret Selting. 2018. Interactional Linguistics: Studying Language in Social Interaction. Cambridge: Cambridge University Press. 
Egan, Thomas. 2013. "Tertia comparationis" in multilingual corpora. In Karin Aijmer \& Bengt Altenberg (eds.), Advances in corpus-based contrastive linguistics: Studies in honour of Stig Johansson, 7-24. Amsterdam: John Benjamins.

Fries, Charles C. 1952. The Structure of English: An Introduction to the Construction of English Sentences. New York: Harcourt, Brace and Company.

Gribanova, Tatiana I. \& Tamara M. Gaidukova. 2019. Hedging in different types of discourse. Training, Language and Culture 3 (2). 85-99. DOI: https://doi.org/10.29366/2019tlc.3.2.6

Handford, Michael. 2010. The language of Business Meetings. Cambridge: Cambridge University Press.

Heritage, John. 2002. Oh-prefaced responses to assessments: A method of modifying agreement/disagreement. In Cecilia E. Ford, Barbara A. Fox \& Sandra A. Thompson (eds.), The Language of turn and sequence, 196-224. New York: Oxford University Press.

Heritage, John \& Marja-Leena Sorjonen. (eds.). 2018. Between Turn and Sequence: TurnInitial Particles Across Languages. Amsterdam/Philadelphia: John Benjamins Publishing Company. DOI: https://doi.org/10.1075/slsi.31

Iliadi, Paraskevi-Lukeriya L. \& Tatiana V. Larina. 2017. Refusal strategies in English and Russian. RUDN Journal of Language Studies, Semiotics and Semantics 8 (3). 531-542. DOI: https://doi.org/10.22363/2313-2299-2017-8-3-531-542

Jefferson, Gail. 2002. Is "no" an acknowledgment token? Comparing American and British uses of $(+) /(-)$ tokens. Journal of Pragmatics 34 (10-11). 1345-1383. DOI: https://doi.org/10.1016/S0378-2166(02)00067-X

Johansson, Stig \& Knut Hofland. 1994. Towards an English-Norwegian parallel corpus. In Udo Fries, Gunnel Tottie \& Peter Schneider (eds.), Creating and using English language corpora, 25-37. Zürich: Rodopi.

Krzeszowski, Tomasz P. 1984. Tertium comparationis. In Jacek Fisiak (ed.), Contrastive Linguistics: Prospects and Problems, 301-312. Berlin: Mouton Publishers.

Lee-Goldman, Russell. 2011. "No" as a discourse marker. Journal of Pragmatics 43 (10). 2627-2649. DOI: https://doi.org/10.1016/j.pragma.2011.03.011

Lewis, Richard. 2019. The cultural imperative: Global trends in the 21 st century. Training, Language and Culture 3 (3). 8-20. DOI: 10.29366/2019tlc.3.3.1

Malyuga, Elena N. \& Michael McCarthy. 2018. English and Russian vague category markers in business discourse: Linguistic identity aspects. Journal of Pragmatics 135.39-52. DOI: https://doi.org/10.1016/j.pragma.2018.07.011

Malyuga, Elena N., Alex Krouglov \& Barry Tomalin. 2018. Linguo-cultural competence as a cornerstone of translators' performance in the domain of intercultural business communication. XLinguae 11(2). 566-582. DOI: 10.18355/XL.2018.11.02.46

Malyuga, Elena N. \& Barry Tomalin. 2014. English professional jargon in economic discourse. Journal of Language and Literature 5(4). 172-180. DOI:10.7813/j11.2014/ $5-4 / 38$

Malyuga, Elena N., Alexander Shvets \& Ilyia Tikhomirov. 2016. Computer-based analysis of business communication language. In Proceedings of 2016 SAI Computing Conference, SAI 2016, 229-232.

McCarthy, Michael. 2002. Good listenership made plain: British and American non-minimal response tokens in everyday conversation. In Randi Reppen, Susan M. Fitzmaurice \& Douglas Biber (eds.), Using corpora to explore linguistic variation, 49-71. Amsterdam: John Benjamins Publishing. DOI: https://doi.org/10.1075/scl.9.05mcc

McCarthy, Michael. 2003. Talking back: "Small" interactional response tokens in everyday conversation. Research on Language and Social Interaction 36 (1). 33-63. DOI: https://doi.org/10.1207/S15327973RLSI3601_3 
McGee, Peter. 2018. Vague language as a means of avoiding controversy. Training, Language and Culture 2 (2). 40-54. DOI: https://doi.org/10.29366/2018tlc.2.2.3

Mikhailov, Mikhail \& Robert Cooper. 2016. Corpus Linguistics for Translation and Contrastive Studies. Abingdon/Oxon: Routledge.

O'Keeffe, Anne \& Svenja Adolphs. 2008. Using a corpus to look at variational pragmatics: Response tokens in British and Irish discourse. In Klaus P. Schneider \& Anne Barron (eds.), Variational Pragmatics, 69-98. Amsterdam: John Benjamins Publishing.

Pope, Emily N. 1976. Questions and Answers in English. The Hague: Mouton.

Quirk, Randolph, Sidney Greenbaum, Geoffrey Leech \& Jan Svartvik. 1985. A Comprehensive Grammar of the English Language. London: Longman.

Raymond, Geoffrey. 2003. Grammar and social organization: Yes/no interrogatives and the structure of responding. American Sociological Review 68 (6). 939-967. DOI: https://doi.org/10.2307/1519752

Sacks, Harvey, Emanuel A. Schegloff \& Gail Jefferson. 1974. A simplest systematics for the organization of turn-taking for conversation. Language 50 (4). 696-735. DOI: https://doi.org/10.1353/lan.1974.0010

Schegloff, Emanuel A. 1982. Discourse as interactional achievement: Some uses of "uh huh" and other things that come between sentences. In Deborah Tannen (ed.), Analysing discourse: Text and talk, 71-93. Washington: Georgetown University Press.

Schegloff, Emanuel A. 1992. Repair after next turn: The last structurally provided defense of intersubjectivity in conversation. American Journal of Sociology 97 (5). 1295-1345. DOI: https://doi.org/10.1086/229903

Schegloff, Emanuel A. 1996. Turn organization: One intersection of grammar and interaction. In Elinor Ochs, Emanuel A. Schegloff \& Sandra A. Thompson (eds.), Interaction and grammar, 52-133. Cambridge: Cambridge University Press.

Schegloff, Emanuel A. 2001. Getting serious: Joke $\rightarrow$ serious "no". Journal of Pragmatics 33 (12). 1947-1955. DOI: https://doi.org/10.1016/S0378-2166(00)00073-4

Stivers, Tanya. 2004. "No no no" and other types of multiple sayings in social interaction. Human Communication Research 30 (2). 260-293. DOI: https://doi.org/10.1111/j.14682958.2004.tb00733.x

Tao, Hongyin. 2003. Turn initiators in spoken English: A corpus-based approach to interaction and grammar. In Pepi Leistyna \& Charles F. Meyer (eds.), Corpus analysis: Language structure and language use, 187-207. Amsterdam/New York: Rodopi. DOI: https://doi.org/10.1163/9789004334410_011

Thompson, Sandra A., Barbara A. Fox \& Elizabeth Couper-Kuhlen. 2015. Grammar in Everyday Talk: Building Responsive Actions. Cambridge: Cambridge University Press.

Tottie, Gunnel. 1991. Conversational style in British and American English: The case of backchannels. In Karin Aijmer \& Bengt Altenberg (eds.), English corpus linguistics, 254-271. London: Longman.

Wong, Jock Onn. 2018. The semantics of logical connectors: Therefore, moreover and in fact. Russian Journal of Linguistics 22 (3). 581-604. DOI: https://doi.org/10.22363/23129182-2018-22-3-581-604

Zalizniak, Anna A. \& Elena V. Paducheva. 2018. Towards a semantic analysis of Russian discourse markers: Pozhaluj, nikak, vsjo-taki. Russian Journal of Linguistics 22 (3). 628-652. DOI: https://doi.org/10.22363/2312-9182-2018-22-3-628-652

\section{Article history:}

Received: 10 November 2020

Accepted: 22 March 2021 


\section{История статьи:}

Дата поступления в редакцию: 10 ноября 2020

Дата принятия к печати: 22 марта 2021

\section{Bionotes:}

Elena N. MAL YUGA is Professor of Linguistics, Head of Foreign Languages Department at the Faculty of Economics, Peoples' Friendship University of Russia, Doctor habil. of Linguistics, Chairperson of the Business and Vocational Foreign Languages Teachers National Association (Russia), Editor-in-Chief of the journals "Issues of Applied Linguistics", and "Training, Language and Culture". Her research interests embrace theory and practice of intercultural professional and business communication, pragmatics, corpus studies and discourse analysis. She authored and co-authored over 300 publications.

\section{Contact information:}

Peoples' Friendship University of Russia

6, Miklukho-Maklaya, Moscow, 117198, Russia

e-mail: malyuga-en@rudn.ru

ORCID: 0000-0002-6935-0661

Michael McCARTHY is Emeritus Professor of Applied Linguistics, University of Nottingham (UK), Adjunct Professor of Applied Linguistics, University of Limerick (Ireland), Visiting Professor of Applied Linguistics at Newcastle University, UK, and Peoples' Friendship University of Russia. He has (co-)authored and (co-)edited 56 books, including "Spoken Language and Applied Linguistics", "The Cambridge Grammar of English", "From Corpus to Classroom: Language Use and Language Teaching", and "The Routledge Handbook of Corpus Linguistics" and (co-)authored 120 academic papers which focus mainly on spoken language. $\mathrm{He}$ is co-founder (with Ronald Carter) of the "CANCODE" spoken English corpus and the "CANBEC" spoken business English corpus.

\section{Contact information:}

University of Nottingham

University Park

Nottingham, NG7 2RD

e-mail: mactoft@aol.com

ORCID: 0000-0001-6795-3816

\section{Сведения об авторах:}

Елена Николаевна МАЛЮГА - профессор лингвистики, заведующая кафедрой иностранных языков экономического факультета Российского университета дружбы народов, доктор филологических наук, председатель Национального объединения преподавателей иностранных языков делового и профессионального общения в сфере бизнеса (Россия), главный редактор журналов «Вопросы прикладной лингвистики» и «Training, Language and Culture». Научные интересы: теория и практика межкультурного профессионального и делового общения, прагматика, корпусные исследования, дискурс-анализ. Автор/соавтор более 300 публикаций.

\section{Контактная информация:}

Российский университет дружбы народов

Россия, 117198, Москва, Миклухо-Маклая, 6

e-mail: malyuga-en@rudn.ru

ORCID: 0000-0002-6935-0661 
Майкл МАККАРТИ - почетный профессор прикладной лингвистики Ноттингемского университета (Великобритания), адъюнкт-профессор прикладной лингвистики Лимерикского университета (Ирландия), приглашенный профессор прикладной лингвистики в Университете Ньюкасла (Великобритания) и Российском университете дружбы народов. Он является (со)автором и (со)редактором 56 книг, в том числе "Spoken Language and Applied Linguistics", "The Cambridge Grammar of English", "From Corpus to Classroom: Language Use and Language Teaching" и "Тhe Routledge Handbook of Corpus Linguistics". Автор/соавтор 120 научных работ, в которых основное внимание уделяется разговорной речи. Соучредитель (совместно с Рональдом Картером) корпуса разговорного английского языка “CANCODE” и корпуса разговорного делового английского языка “CANBEC”.

\section{Контактная информация:}

University of Nottingham

University Park

Nottingham, NG7 2RD

e-mail: mactoft@aol.com

ORCID: 0000-0001-6795-3816 